\title{
FATAL BASILAR ARTERY OCCLUSION FOLLOWING CERVICAL SPINE INJURY
}

\author{
By Robert M. Woolsey, M.D. and Hyung D. Chung, M.D. \\ Spinal Cord Injury Service, St Louis Veterans Administration Medical Center and The \\ Department of Neurology and Neuropathology of St. Louis University St Louis, Missouri \\ 63125, U.S.A.
}

DESPITE the intimate relationship between the cervical spine and vertebral artery, symptoms referable to vertebral artery damage have rarely been reported in association with cervical spine fractures. The following case of fatal basilar artery occlusion in a patient with vertebral artery thrombosis at the site of a cervical spine fracture is somewhat unique.

\section{Case Report}

A 3 I-year-old man was injured in an automobile accident on $27 / 5 / 78$. When examined shortly thereafter, he was found to have no sensation or movement in his lower extremities. He had intact pain sensation in his right thumb and index finger and along the lateral aspect of his arm and forearm but loss of pain sensation in his other fingers and the medial aspect of his arm and forearm. He was able to flex his right arm and abduct his right shoulder with normal strength. He could extend his right wrist with about 25 per cent normal strength. The remaining muscles of the right arm were paralysed. The left arm was completely immobile, cold and without arterial pulses.

Cervical spine X-rays were 'normal'. X-rays of the chest showed fractures involving the second, fourth and fifth ribs, the clavicle and scapula on the left side. There was haziness of the left upper lobe of the lung. An arteriogram, by means of a catheter placed in the left subclavian artery, showed complete occlusion of that vessel at the origin of the thyrocervical trunk. In addition, dye did not pass up the left vertebral artery beyond the C6 vertebral level. This was confirmed on multiple injections.

A left subclavian thrombectomy was performed; however, the condition of the left arm did not improve and it was amputated.

On 2I/6/78, the patient was transferred to the Spinal Cord Injury Service of the St Louis Veterans Administration Medical Center. Upon arrival, he complained of severe neck pain and shock-like and tingling sensations extending up the back of his neck and down over the upper aspect of both shoulders. Cervical spine X-rays showed a $\mathrm{I} \mathrm{cm}$ anterior dislocation of $\mathrm{C}_{5}$ on $\mathrm{C} 6$.

Using Gardner-Wells tongs and $34 \mathrm{lb}$ of traction, the cervical dislocation was reduced. Alignment was maintained in slight hyperextension with $\mathrm{I} 4 \mathrm{lb}$ of traction.

The patient did well until 29/6/78 when, while undergoing passive movement of his lower extremities, he stated that he felt as though he were about to 'black out'. He then became unconscious and apneic. His pulse remained normal. He became cyanotic but with immediate respiratory support, his colour returned to normal. The pupils were examined several minutes after the onset of unconsciousness and were noted to be dilated and fixed to light. Irrigation of each ear with ice water for one minute produced no oculomotor response. An EKG showed no abnormalities. The patient remained comatose and apneic. His blood pressure progressively declined in spite of large doses of vasopressor agents. He ceased to have a heartbeat 2 hours after the onset of unconsciousness.

At autopsy, the basilar artery was occluded throughout its entire length by a recent thrombus which extended a short distance into the left vertebral artery (Fig. I). The 


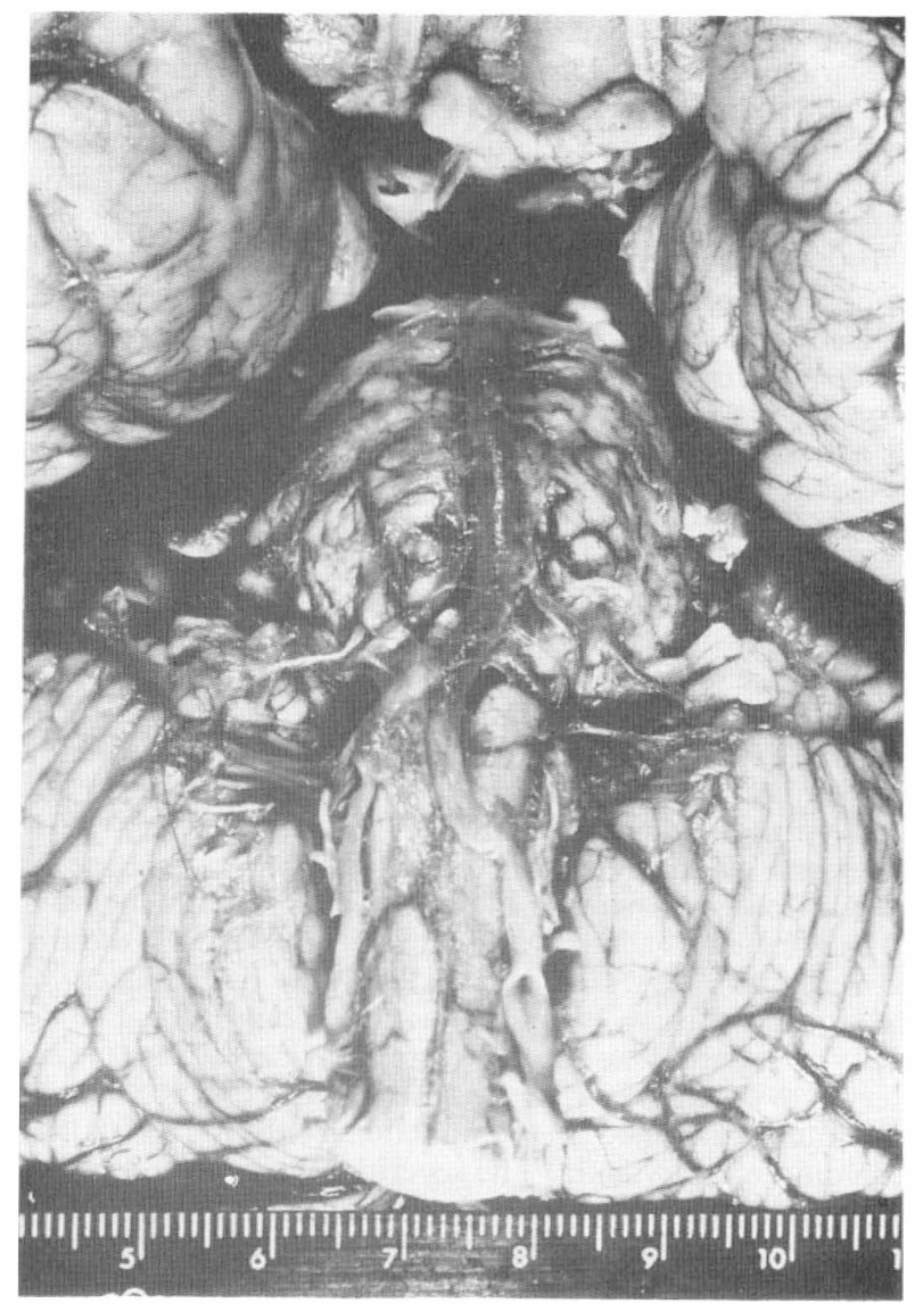

FIG. I

brain stem appeared slightly dusky but was otherwise grossly normal. The lower half of the cervical spinal cord was soft and atrophic. The left vertebral artery was occluded by an organised thrombus at the level of the 6th cervical vertebrae. Microscopically, there was ischaemic necrosis of some neurones of the occulomotor, abducens, facial, superior olivary, trigeminal and dentate nuclei bilaterally. Similar changes were present in some Purkinje cells. Multiple sections of the cerebral cortex appeared normal.

\section{Discussion}

Evidently, this patient injured and thrombosed his left vertebral artery at the time of his accident. Thirty-three days later, the basilar artery became occluded in its entirety resulting in acute vascular insufficiency of the mid-brain, pons and medulla.

As a rule, basilar artery occlusion results in patchy infarction of the brain $17 / 3-B$ 
stem and cerebral structures which it supplies. The resulting clinical manifestations include various combinations of visual defects, diplopia, limb ataxia and weakness, dysarthria and dysphagia (Kubic \& Adams, I946; Biemond, I95I; Millikan et al., 1955). Only rarely is the collateral circulation so inadequate that massive brain stem destruction results producing coma, cranial areflexia, quadriplegia and apnea (Otomo, I966; Plum \& Posner, 1972).

Emboli to the basilar territory do not commonly cause extensive brain stem destruction since an embolus of sufficient size to traverse the vertebral artery would be unlikely to occlude the larger diameter basilar artery (Carter, 1964). Such embolic fragments usually lodge in one or both posterior cerebral arteries producing some variety of visual field defect.

Whether the fresh clot in the basilar artery of this patient represents an embolus or a thrombosis cannot be determined with certainty. The extent of the clot and the abrupt simultaneous failure of all brain stem functions favour the embolic alternative.

Suechting and French (1955) and Schneider and Crosby (1959) were first to comment upon the possibility that vertebral artery involvement in cervical spine injuries might produce circulatory insufficiency in the brain stem. Subsequently, Carpenter (196I) reported a patient who experienced vertigo and fatal respiratory arrest shortly after a traumatic $\mathrm{C}_{7}$ compression fracture. At autopsy, the left vertebral artery at the fracture site was occluded by a thrombus which extended upward to involve the left posterior inferior cerebellar artery with resultant infarction of portions of the medulla and cerebellum. Simeone and Goldberg (I969) described a case very similar in its clinical and pathological aspects. Our case differs in that there was a latent period of 4 weeks between the angiographically demonstrated vertebral artery occlusion and the fatal basilar artery occlusion.

Vertebral artery occlusion in spinal fractures would appear to be rare judging from the paucity of reported cases. However, Davis et al. (I97I) reported that the vertebral artery was lacerated or thrombosed in three of 50 acute fatal cases of cranial-spinal injury examined in conjunction with the office of the medical examiner of Baltimore, Maryland. The severity of injury and the disproportionate number of high cervical injuries preclude the translation of these findings into an expected incidence of vertebral artery damage in surviving patients with more conventional levels of cervical spine injury. Wener et al. (1974) reported that among six patients examined angiographically within a few hours after trauma, the vertebral artery was occluded in one. Because of the small number of cases, it is inappropriate to infer an expected incidence of vertebral artery thrombosis associated with cervical spine fracture. Nevertheless, these reports suggest that vertebral artery damage in cervical fractures may not be as rare as has been previously supposed.

\section{SUMMARY}

A patient rendered acutely quadriplegic in an automobile accident was shown by angiography to have occlusion of the left vertebral artery. One month later, he abruptly became unconscious, apneic and died. Autopsy showed an organised thrombus in the left vertebral artery and a fresh thrombus occluding the entire basilar artery. This case differs from previously reported cases of traumatic vertebral artery thrombosis wherein symptoms of brain stem infarction were more immediately evident. 
RÉSUMÉ

Un homme fut rendu soudain quadriplégic après un accident d'automobile. L'artériographie démontra une occlusion de l'artère vertébrale gauche. Un mois après l'accident, il y eut un début brutal de coma, d'apnea, et il mourut. L'autopsie démontra un thrombus organisé dans l'artère vertébrale gauche et un nouveau thrombus qui ferma complètement le tronc basilarire. Ce cas est différent des autres descriptions d'occlusions traumatiques de l'artère vertébrale parceque les symptômes de ramollissement du tronc cérébral n'étaient pas immediats.

\section{ZUSAMMENFASSUNG}

Ein Patient, der durch einen Automobilunfall akut tetraplegisch wurde, hatte eine Occlusion der vertebralen Arterie, die durch Angiographie demonstriert wurde. Einen Monat später wurde er plötzlich bewusstlos, hatte einen Atemstillstand und starb. Die Autopsie presentierte einen organisierten Thrombus in der linken vertebralen Arterie und einen frischen Thrombus der die gesamte basilare Arterie verstopfte. Daher unterscheidet sich dieser Fall von anderen früher berichteten Fällen traumatischer vertebralen Arterien Thrombose, in denen sich Symptôme einer Hirnstamm Infarction schneller offenbarten.

\section{REFERENCES}

BIEmond, A. (I95I). Thrombosis of the basilar artery and the vascularization of the brain stem. Brain, 74, 300.

CARPENTER, S. (I96I). Injury of neck as a cause of vertebral artery thrombosis. F. Neurosurg., 18, 849 .

CARTER, A. B. (I964). Cerebral Infarction. Macmillan Co., New York.

Davis, D., Bohlman, H., Walker, A. E., Fisher, R., \& Robinson, R. (I97I). The pathological findings in fatal craniospinal injuries. F. Neurosurg., 34, 603.

Отомо, E. (I966). Beta wave activity in the electroencephalogram in cases of coma due to acute brain-stem lesions. F. Neurol. Neurosurg. Psychiat., 29, 383.

Kubik, C. S. \& AdAMS, R. D. (1946). Occlusion of the basilary artery-a clinical and pathological study. Brain, 69, 73.

Plum, F. \& Posner, J. B. (1972). The Diagnosis of Stupor and Coma. F. A. Davis Co., Philadelphia, 2nd edition.

SCHNEIDER, R. C. \& CROSBY, E. C. (1959). Vascular insufficiency of brain stem and spinal cord in spinal trauma. Neurology, 9, 643.

Siekert, R. G. \& Millikan, C. H. (I955). Studies in cerebrovascular disease. II. Some clinical aspects of thrombosis of the basilar artery. Proc. Staff Meetings Mayo Clinic, 30, 93.

Simeone, F. A. \& Goldberg, H. I. (I968). Thrombosis of the vertebral artery from hyperextension injury to the neck. F. Neurosurg., 29, 540 .

SueChTing, R. L. \& FRENCH, L. A. (1955). Posterior inferior cerebellar artery syndrome following a fracture of the cervical vertebra. F. Neurosurg., 12, I87.

Wenter, L., DiChIRO, G. \& GARGOUR, G. W. (1974). Angiography of cervical cord injuries. Radiology, 112, 597. 